Article

\title{
Field Surveys of Non-Residential Solar Water Heating Systems in Taiwan
}

\author{
Wei-Min Lin ${ }^{1}$, Keh-Chin Chang ${ }^{2}$, Yi-Mei Liu ${ }^{2}$ and Kung-Ming Chung ${ }^{2, *}$
}

1 Department of Accounting Information, Tainan University of Technology, 529 Jhongjheng Rd., Yongkang, Tainan, Taiwan 710; E-Mail: t20043@mail.tut.edu.tw

2 Energy Research Center, National Cheng Kung University, 2500 Sec. 1, Chung-Cheng S. Rd, Guiren, Tainan, Taiwan 711; E-Mails: kcchang@mail.ncku.edu.tw (K.-C.C.); monica0701@ckmail.ncku.edu.tw (Y.-M.L.)

* Author to whom correspondence should be addressed; E-Mail: kmchung@mail.ncku.edu.tw; Tel.: +886-62392811; Fax: +886-2391915.

Received: 21 December 2011; in revised form: 31 January 2012 / Accepted: 6 February 2012 / Published: 7 February 2012

\begin{abstract}
To develop indigenous alternative and renewable energy resources, long-term subsidy programs (1986-1991 and 2000-present) for solar water heaters have been enforced in Taiwan. By the end of 2010, the total installed area of solar collectors had exceeded 2 million square meters. However, over $98 \%$ of solar water heaters were used in residential systems for hot water production, with the areas of installed solar collector being less than 10 square meters. There were only 98 systems with area of solar collectors installed exceeding 100 square meters put into operation from 2001 to 2010. These systems were mainly installed for water heating in dormitories, swimming pools, restaurants, and manufacturing plants. In the present study, a comprehensive survey of these large-scale solar water heaters was conducted. The objectives of the survey were to assess the system performance and to collect feedback from individual users. It is found that lack of experience in system design and maintenance are the key factors affecting reliable operation of a system. Hourly, daily and long-term field measurements of a dormitory system were also examined to evaluate its thermal efficiencies. Results indicated that thermal efficiency of the system is associated with the daily solar radiation. Hot water use pattern and operation of auxiliary heater should be taken into account in system design.
\end{abstract}

Keywords: large-scale solar water heater; field measurement; thermal performance 


\section{Solar Water Heaters in Taiwan}

Despite the intermittent nature of renewable energy resources, they are sustainable and clean energy assets derived from Nature. Besides the energy savings, applications of renewable energy technologies also yield environmental benefits with reduction in production of air pollutants and release of greenhouse gases into the atmosphere, both of which can mitigate climate changes. Furthermore, solar thermal energy is known to be the most widely used in many countries [1,2]. Solar water heaters (SWHs) also offer significant protection to the environment and should be employed whenever possible in order to achieve a sustainable future [3]. Taiwan is located in the subtropics with abundant sunshine. Use of solar water heaters began in 1978. However, the number of solar water heaters installed in the early 1980s was quite limited due to their higher capital cost compared with conventional liquefied petroleum gas or natural gas water heaters. To develop an indigenous alternative and renewable energy resources, the government of Taiwan introduced several subsidy programs (1986-1991, 2000-2008 and 2009-present) for solar water heaters. As shown in Figure 1, the subsidy programs, which would result in a shorter payback time [4], played a critical role in the diffusion of solar water heaters in Taiwan. In 1999, the area of solar collector installed (ASC) was only about $56,500 \mathrm{~m}^{2}$. With the subsidy programs, the solar water heaters installed reached the peak of 24,684 units $\left(\mathrm{A}_{\mathrm{SC}}=114,428 \mathrm{~m}^{2}\right)$ in 2006 . Solar water heaters have been proved to be reliable and economical in hot water production. This is also the most successful story for the application of renewable energies in Taiwan.

Figure 1. Solar water heaters installed from 2001 to 2010.

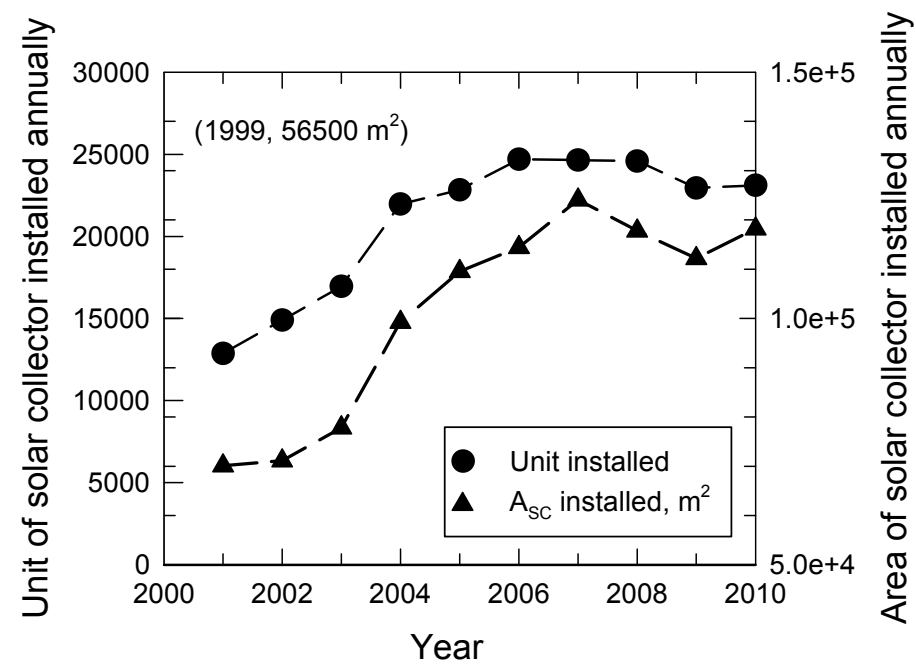

Several factors influence hot water use patterns in different countries, including the lifestyle, climate, household size, age of family members and the required temperature at the point of use [5-9]. In Taiwan, a general survey of users was conducted by Chang et al. [10-12]. In terms of $\mathrm{A}_{\mathrm{SC}}$, solar water heaters were categorized into three groups as shown in Table 1. It is worth noting that over 98\% of solar water heaters had $A_{S C} \leq 10 \mathrm{~m}^{2}$. As a rule of thumb for system design of a solar water heater in Taiwan, the daily hot water consumption for each person corresponds to the hot water production by $\mathrm{A}_{\mathrm{SC}} \approx 1 \mathrm{~m}^{2}$. According to the household structure in Taiwan, a system with $\mathrm{A}_{\mathrm{SC}} \leq 10 \mathrm{~m}^{2}$ would more likely be used in the domestic sector (or residential systems). Furthermore, there were only 98 systems 
installed with $A_{S C} \geq 100 \mathrm{~m}^{2}$ (large-scale systems) from 2001 to 2010. In the present study, both desk and field surveys for these large-scale solar water heaters were conducted to explore barriers and constraints to market expansion. Findings of the survey would assist policy-makers in formulating effective countermeasures and strategies.

Table 1. Solar water heaters installed in terms of $A_{S C}$.

\begin{tabular}{ccccc}
\hline $\mathbf{A}_{\mathbf{S C}}, \mathbf{~ m}^{\mathbf{2}}$ & Below 10 & $\mathbf{1 0 - 1 0 0}$ & Above 100 & Total \\
\hline 2001 & 12,576 & 277 & 8 & 12,861 \\
2002 & 14,557 & 321 & 6 & 14,884 \\
2003 & 16,600 & 352 & 4 & 16,956 \\
2004 & 21,612 & 349 & 9 & 21,970 \\
2005 & 22,496 & 326 & 8 & 22,830 \\
2006 & 24,369 & 303 & 12 & 24,684 \\
2007 & 24,288 & 354 & 4 & 24,646 \\
2008 & 24,216 & 359 & 16 & 24,591 \\
2009 & 22,397 & 525 & 23 & 22,945 \\
2010 & 22,684 & 410 & 10 & 23,106 \\
\hline
\end{tabular}

\section{Large-Scale Solar Water Heaters}

According to the "Measures for Promoting Solar Water Heaters", in order to obtain a subsidy a user must file an application form. For a large-scale solar water heater, the layout of the system and its design criteria also have to be submitted. A review committee then evaluates the proposal, which mainly includes local weather conditions (duration of sunshine hours, insolation and local average temperature) and field piping. Comments from reviewers would assist the installer in revising the system design. In addition, product marketability could not be assessed solely on the basis of word of mouth or previous experiences with the product rather than actual thermal performance. Thus, certifications of a solar collector or a solar water heater, in which the standards have been enforced by the government of Taiwan since the first subsidy program in 1986, are required when filing for a rebate. For a solar collector, the Chinese National Standards (CNS 15165-1-K8031-1) are in compliance with the existing international standards. The standard specifies an outdoor test method to determine steady-state and quasi-steady-state thermal performance of solar collectors under natural solar radiance, which should be more than $800 \mathrm{~W} / \mathrm{m}^{2}$. The wind speed should be within $2-4 \mathrm{~m} / \mathrm{s}$. In addition, the standard specifies conditions and apparatus specifications for performing tests with acceptable results. In Table $2, \mathrm{~F}_{\mathrm{R}}(\tau \alpha)$ and $\mathrm{F}_{\mathrm{R}} \mathrm{U}_{\mathrm{L}}$ are the intercept and slope of collector efficiency curve (heat loss), respectively. Note that the metal type solar collector is a stainless or copper flat plate with selective coating while there is no glass cover for the unglazed type collector. Furthermore, the thermal efficiency of a solar water heater (CNS 12558-B7277, $\eta \geq 0.5$ ) is given as the ratio of useful heat absorbed by a solar water heater to incoming solar energy on solar collectors. The standard specifies an outdoor test method. The test conditions specify the daily solar radiation per square meter $\left(\geq 7 \mathrm{MJ} / \mathrm{m}^{2}\right)$, the average wind speed $(<4 \mathrm{~m} / \mathrm{s})$, fluid initial temperature $T_{i}$ and ambient air temperature $T_{a}$. The thermal efficiency is calculated using the following formula: 


$$
\eta=\mathrm{MC}_{\mathrm{p}}\left(\mathrm{T}_{\mathrm{f}}-\mathrm{T}_{\mathrm{i}}\right) /\left(\mathrm{A}_{\mathrm{g}} \mathrm{G}\right)
$$

where: $\mathrm{C}_{\mathrm{p}}$ : specific heat, $\mathrm{MJ} /\left(\mathrm{kg} \cdot{ }^{\circ} \mathrm{C}\right)$

$\mathrm{T}_{\mathrm{i}}$ : initial temperature in the hot water storage tank, ${ }^{\circ} \mathrm{C}$

$\mathrm{T}_{\mathrm{f}}$ : final temperature in the hot water storage tank, ${ }^{\circ} \mathrm{C}$

$\mathrm{A}_{\mathrm{g}}$ : effective area of solar collector, $\mathrm{m}^{2}$

$\mathrm{G}$ : daily solar radiation per square meter, $\mathrm{MJ} / \mathrm{m}^{2}$

Table 2. Standards of flat-plate solar collector (1989-present).

\begin{tabular}{cc|cc}
\hline \multicolumn{2}{c|}{ Glazed Metal Type } & \multicolumn{2}{c}{ Unglazed Type } \\
\hline $\mathbf{F}_{\mathbf{R}}(\boldsymbol{\tau} \boldsymbol{\alpha})$ & $\mathbf{F}_{\mathbf{R}} \mathbf{U}_{\mathbf{L}}$ & $\mathbf{F}_{\mathbf{R}}(\boldsymbol{\tau \alpha})$ & $\mathbf{F}_{\mathbf{R}} \mathbf{U}_{\mathbf{L}}$ \\
\hline$\geq 0.75$ & $\leq 7.0$ & $\geq 0.85$ & $\leq 20$ \\
\hline
\end{tabular}

Furthermore, the ratio of volume of storage tank to solar collector area typically ranges from 50 to 80 liters $/ \mathrm{m}^{2}$. For a large-scale solar water heater, besides the climatic conditions, both total daily use and peak hourly use have to be taken into consideration when sizing the system.

According to the desk survey, 98 large-scale solar water heaters (94 flat-plate solar collectors and four evacuated-tube solar collectors) were installed by 30 installers from 2001 to 2010 . Among these installers, 16 installed one large-scale system and only two designed more than 10 systems during this period. Thus, most installers still lacked experience in system design. Then in terms of applications, these large-scale solar water heaters were categorized into four groups, namely for dormitories (81 systems), swimming pools (13 systems), manufacturing plants and restaurants (four systems), as shown in Figure 2. Note that unglazed flat-plate type solar collectors (cheaper in cost, four systems) were adopted by some swimming pools and were installed on the tilt roof, which might encounter less wind loads during typhoon attack in summer and autumn seasons. However, $F_{R}(\tau \alpha)$ and $F_{R} U_{L}$ of solar collectors are associated with their orientation and tilt angle, which would affect the thermal efficiency of a system.

Figure 2. Applications of solar water heaters.

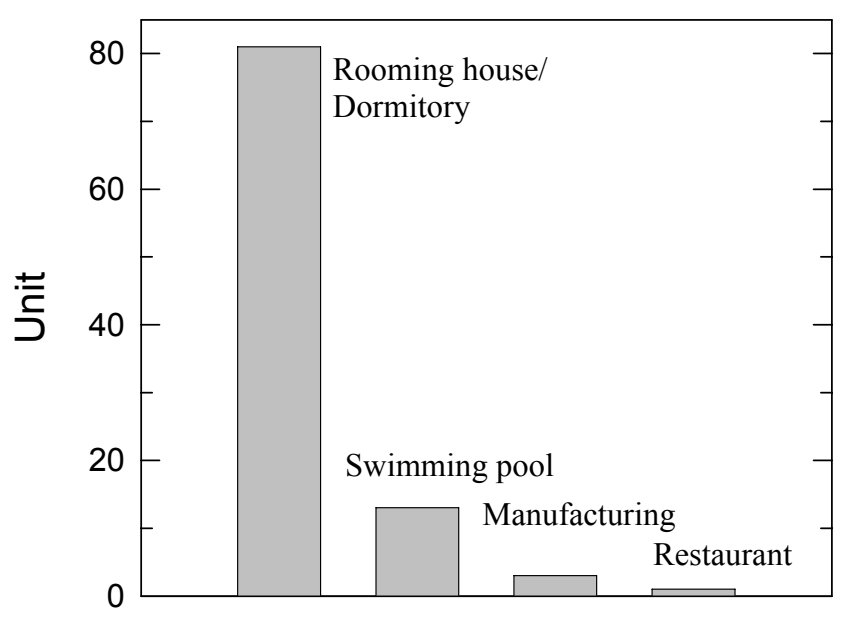




\section{Operation of Solar Water Heaters}

The energy savings during the lifetime of a solar water heater are associated with the system operation and its durability. Several key issues should be addressed, including: (1) reliability (solar collectors and auxiliary system); (2) efficiency; and (3) maintenance (cost and staff). In comparison with other types of water heaters (electric heating, kerosene heater or liquefied petroleum gas heater), hot water production by a solar water heater is strongly associated with local insolation or duration of sunshine hours. Nearly all residential systems in Taiwan had an electrical boost element, which would supply hot water to the households during rainy days. For large-scale solar water heaters, the system was usually integrated with a kerosene heater as an auxiliary element.

The efficiency of a solar water heater is associated with the net savings in fuel or electricity. As mentioned above, most large-scale solar water heaters were integrated with kerosene heaters. For dormitories, regulation of hot water supply was usually set, e.g., from 17:00 to 22:00. In general, reduction in cost of fuel was reported. However, there was one system for dormitory application without regulation of hot water supply. Therefore, hot water consumption, not only for bathing, was much higher than expected and there were no net fuel savings at all. Thus, the system was in operation only for two years and was replaced by electric water heaters thereafter. The students were then charged individually in accordance with the electricity consumed. Such changes led to a significant decrease in hot water consumption.

Maintenance is another critical issue for long-term operation of a large-scale solar water heater $[6,13]$. In general, most systems in Taiwan have not been well maintained due to neglect or unqualified maintenance staff. Leakage of gate valves and deterioration of sealing have been reported from time to time. Thermal insulation degradation is also common. For systems near the coastline, corrosion due to salty air can result in severe degradation of absorber paint as well as corrosion of supporting structures and casings. In addition, instances of broken glasses, as shown in Figure 3, were also reported. This might be related to the impact of debris during typhoon seasons. Finally, dust accumulating on the glass surface would reduce the thermal efficiency of solar collectors. Regular maintenance is required.

Figure 3. Broken glass and dust accumulation.

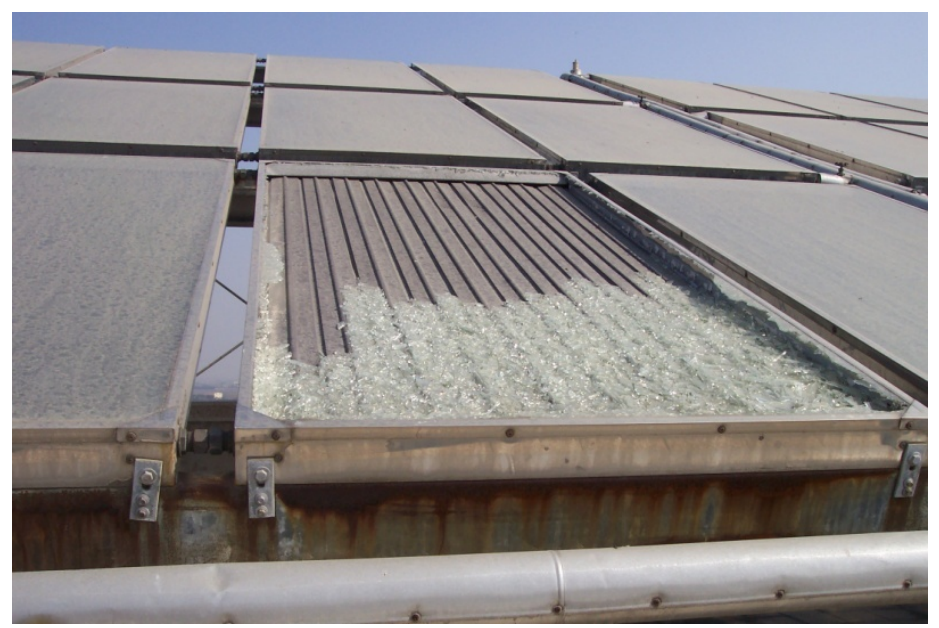




\section{Setup of Field Survey}

In Taiwan, most large-scale solar water heaters were installed for hot water production in dormitories. However, there is limited information on the open literature regarding the thermal performance of such a system. In view of this, Li-Jen Senior High School, located in southern Taiwan near the Tropic of Cancer $\left(23^{\circ} 27^{\prime} 38^{\prime \prime} \mathrm{N}, 120^{\circ} 27^{\prime} 22^{\prime \prime} \mathrm{E}\right)$, was chosen as our case school for evaluating the performance of the installed solar water heaters. Figure 4 shows the two independent solar water heaters for the boys' and girls' dormitories. The solar collectors facing south were installed on the roof with a tilt angle of $18.5^{\circ}$. Detailed specifications of the systems are shown in Table 3, in which there are forty six and thirty glazed flat-plate solar collectors for the girls' and boys' dormitories, respectively. Pumps are used for forced circulation. The systems have been in operation since September 2007. In this study, only the field survey findings for the system installed in the girls' dormitory are discussed.

Figure 4. Solar water heaters at Li-Jen Senior High School.

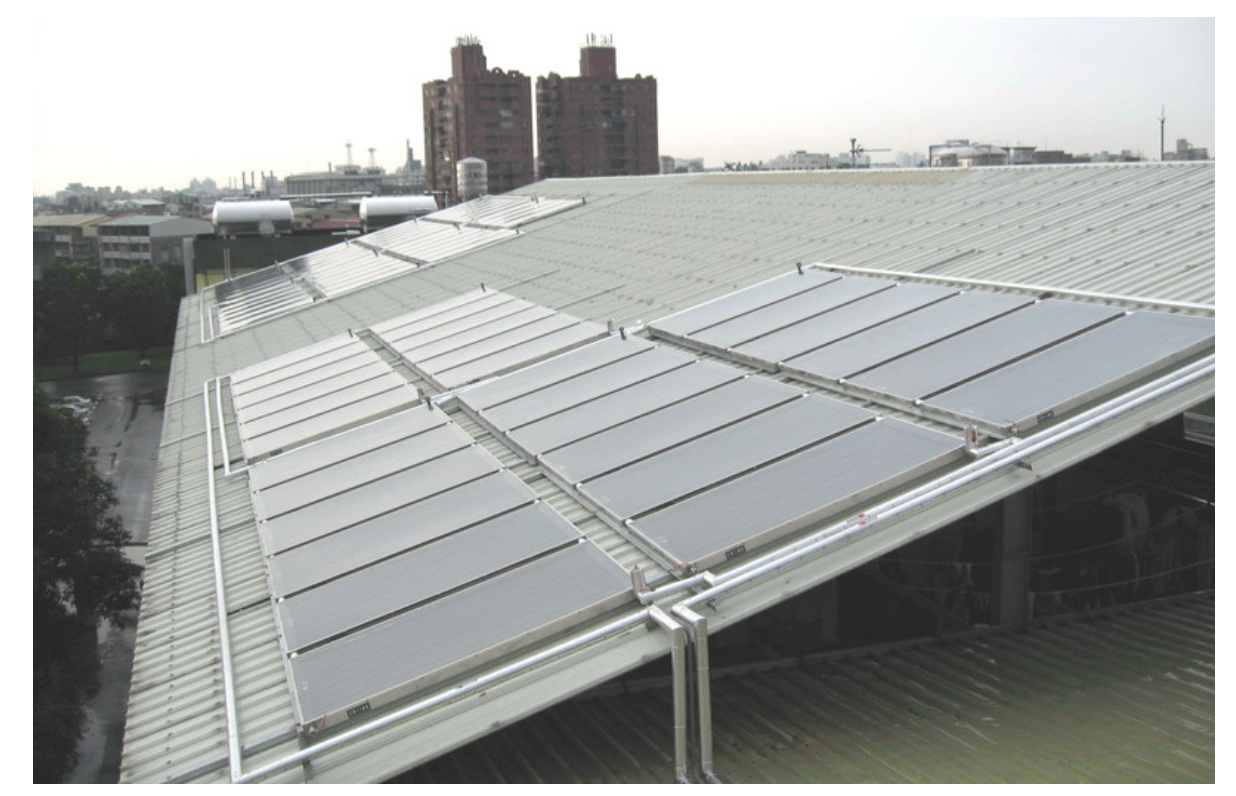

Table 3. Arrangement of large-scale systems at Li-Jen Senior High School.

\begin{tabular}{ccc}
\hline Dormitory & Boys & Girls \\
\hline Type of Collectors & Glazed flat-plate & Glazed flat-plate \\
No. of Collectors & 30 & 46 \\
Total Collector Area & $57 \mathrm{~m}^{2}$ & $84.7 \mathrm{~m}^{2}$ \\
No. of Storage Tanks & $2(1$ with auxiliary heater $)$ & 2 (1 with auxiliary heater) \\
Tank Volume (each) & 2500 liters & 3750 liters \\
\hline
\end{tabular}

To investigate the actual operation conditions of the system, several monitoring devices were installed. As seen in Figure 5, a precision spectral pyranometer (Eppley Laboratory, Inc., model PSP)is set up near the system to determine the incident solar radiation values while a Vector Instruments low-power anemometer (ModelA100L2) records the local wind speed. Two Macnaught flow meters (Model M2SSP-1R) are located in the cold water supply line to the hot water storage tank (hot water consumption) and in the circulation line from the bottom of the storage tank to the inlet of the 
collectors (circulation flow rate), respectively. There are 14 platinum resistance thermometers (Izuder Enterprise, 1/10 DIN Class B) installed to monitor the local water temperature. In addition, energy consumption of the auxiliary electric heater is recorded by the power meter. The data from monitoring devices are sampled every 10 seconds by National Instrument (NI) data acquisition system (Model cFP-AI-110 and cFP-RTD-124) and transmitted synchronously to the host computer at the Energy Research Center, National Cheng Kung University, through the Internet.

Figure 5. Schematic drawing of monitoring devices.

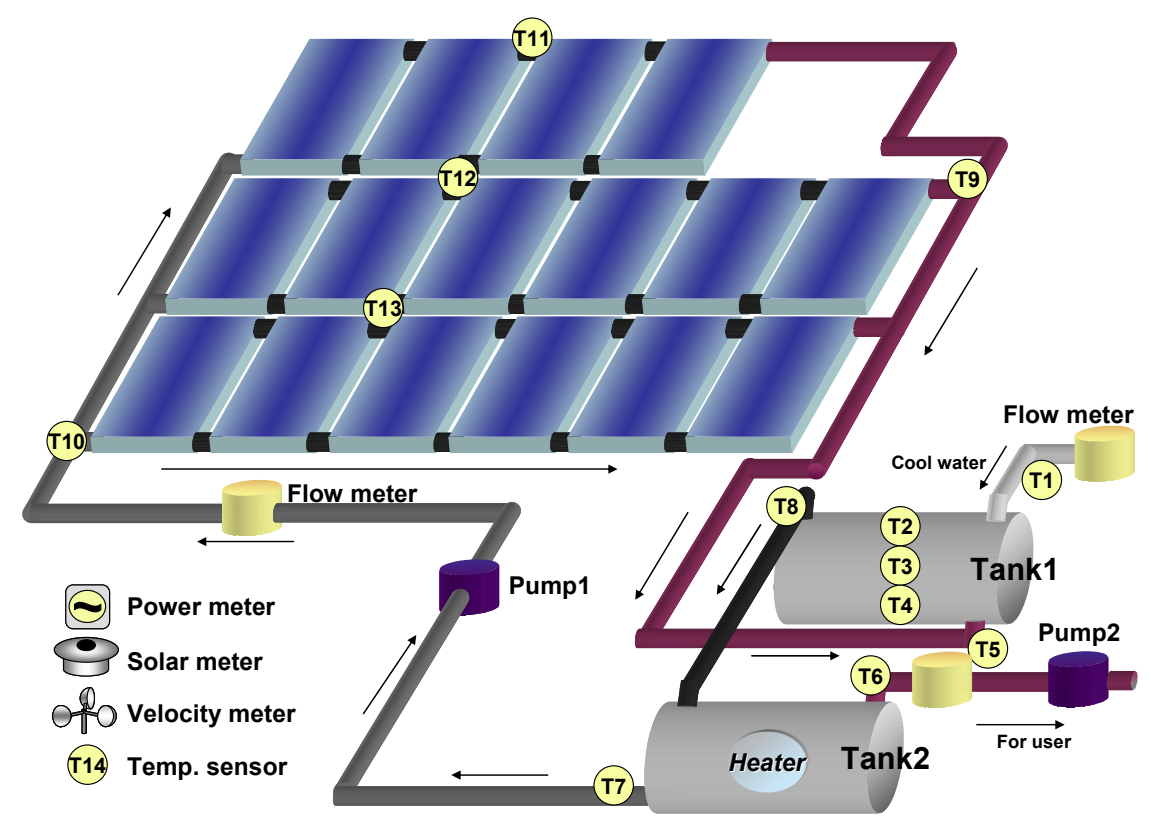

\section{Thermal Performance Analysis}

Although the solar contribution is usually reported on a monthly or annual basis to avoid daily variation of solar insolation, there is high demand for hot water supply from November to January in Taiwan. Thus, the data from November 11th 2009 till January 19th 2010 were used for the present study. Take the daily record on December 2nd 2009 for example. The plots of solar radiation and ambient temperature data are shown in Figure 6.

Figure 6. Daily variations of solar radiation and ambient temperature.

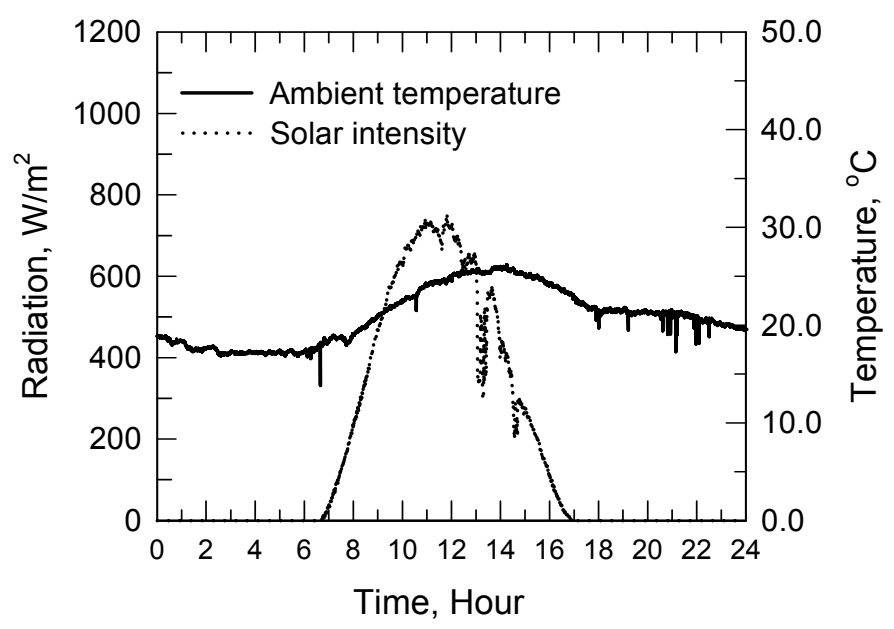


Throughout the day and night, the ambient temperature ranged from $18{ }^{\circ} \mathrm{C}$ to $25{ }^{\circ} \mathrm{C}$, and a peak solar radiation of over $700 \mathrm{~W} / \mathrm{m}^{2}$ was also observed. The daily solar radiation was about $4.16 \mathrm{kWh} / \mathrm{m}^{2}$ or $352.4 \mathrm{kWh}$ of energy from the Sun for the system. Furthermore, the measured data of the inlet and outlet temperature of the collectors are shown in Figure 7.

Figure 7. Inlet and outlet temperature of collectors.

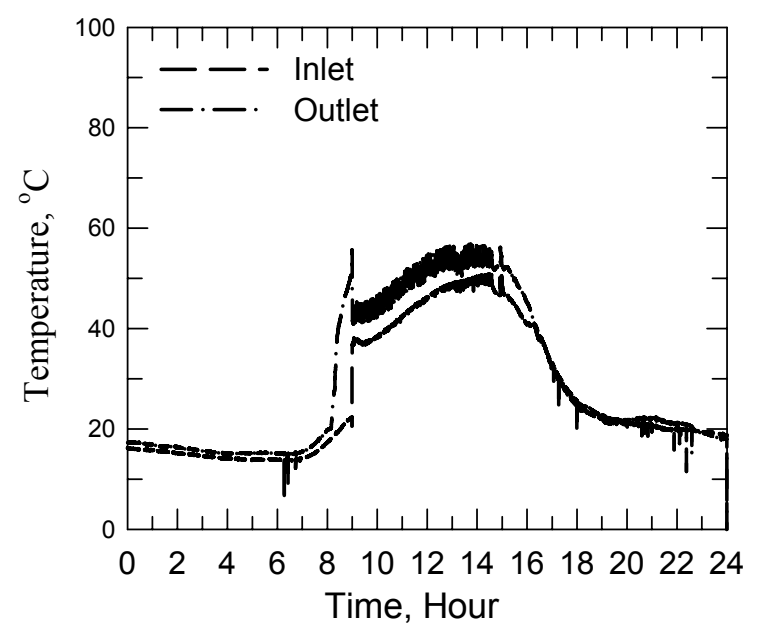

As can be seen, the rises in water temperature were associated with solar radiation during the day (from 06:30 to 17:00). The peak inlet and outlet temperature of collectors were $50.6{ }^{\circ} \mathrm{C}$ and $56.6{ }^{\circ} \mathrm{C}$, respectively. These maxima corresponded to the temperature rise of about $30{ }^{\circ} \mathrm{C}$ in comparison with the ambient temperature. Furthermore, hot water usage is a critical factor for thermal efficiency of a solar water heater. In Figure 8, hot water consumption was mostly concentrated in periods from 16:30 to 18:00 and from 20:00 to 22:30, indicating living habits of students.

Figure 8. Hot water consumption patterns.

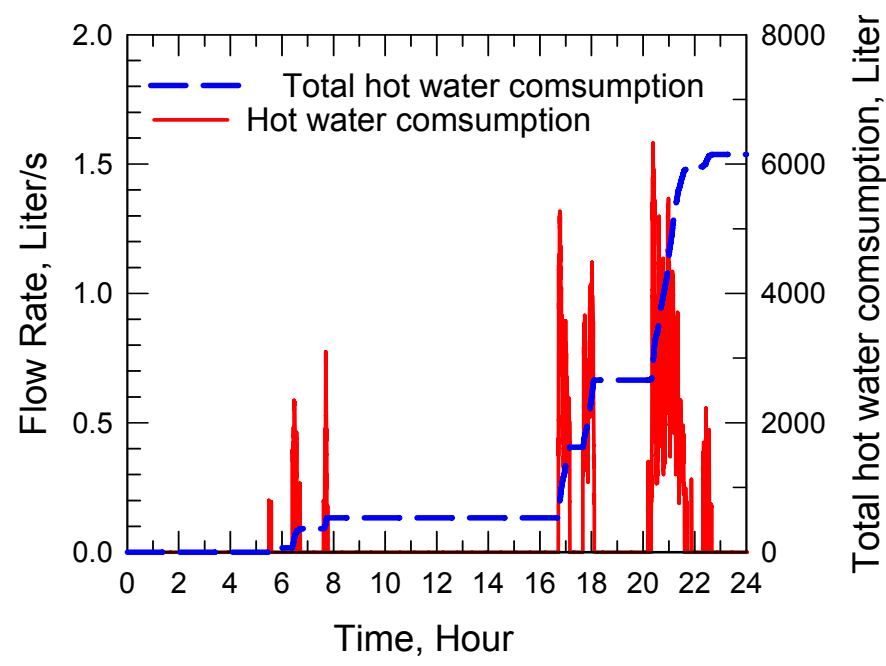


Less hot water was used for bathing or washing up in the early morning (from 06:00 to 08:00). The daily hot water consumption was calculated to be 6148 liters. Regarding energy consumption of the system, the actual demand for water heating energy can be evaluated from the temperature of cold water supply and the faucet. Operation of the auxiliary heater corresponds to the energy consumed, which was monitored by the power meter. Note that in Figure 9, the actual demand for energy consumption is slightly lower than the energy consumed between 15:30 and 16:30. This is because the auxiliary heater was switched on at 15:30 while the actual hot water consumption began only after 16:30. Moreover, there is a big difference between the actual demand for energy consumption and the energy consumed after 22:00, which is the second peak hot water consumption period. According to the measured data, the daily heating energy for hot water production was computed to be $250 \mathrm{kWh}$ while the energy consumption of the auxiliary heater was $136 \mathrm{kWh}$, indicating that the daily solar contribution is about $45.6 \%$. Note that the designed daily solar contribution is $58 \%$ and optimal control of the auxiliary heater should be further addressed.

Figure 9. Cumulative energy consumption.

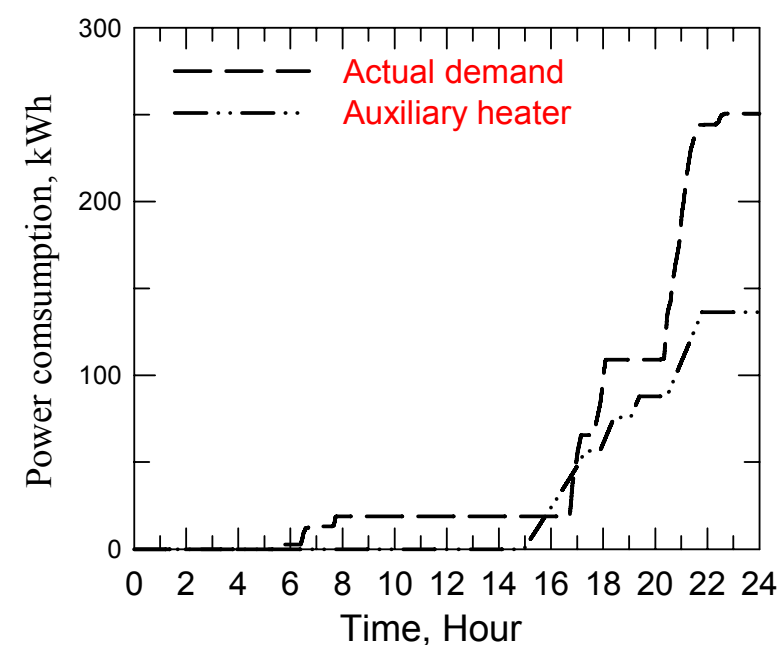

Figure 10 shows the statistics of hot water consumption between November 2009 and January 2010. Since the weekends are days with the least demand for hot water use in the dormitory, the data are not included in the graph. As can be seen, the daily hot water consumption ranged from 2500 liters to 9000 liters. In Taiwan, the average hot water consumption per person is 60 liters at $50{ }^{\circ} \mathrm{C}$ for bathing. It is considered that the fluctuations in daily hot water consumption should be strongly related to ambient temperature. As shown in Figure 11, the demand for hot water from students could increase three fold with a $10{ }^{\circ} \mathrm{C}$ drop in ambient temperature. Assuming a constant level of daily solar radiation, more hot water consumption also implies that the water heating energy would come mainly from the auxiliary heater at lower ambient temperature. Furthermore, the thermal efficiency of the system, which is associated with the collector's thermal efficiency and the demand for hot water [14], is one of the major concerns in the present study. According to CNS 12558-B7277, the amount of collected solar energy divided by the total energy incident on the collectors $(\eta)$ should exceed 0.5 for a residential solar water heater. 
Figure 10. Hot water consumption at Li-Jen Senior High School.

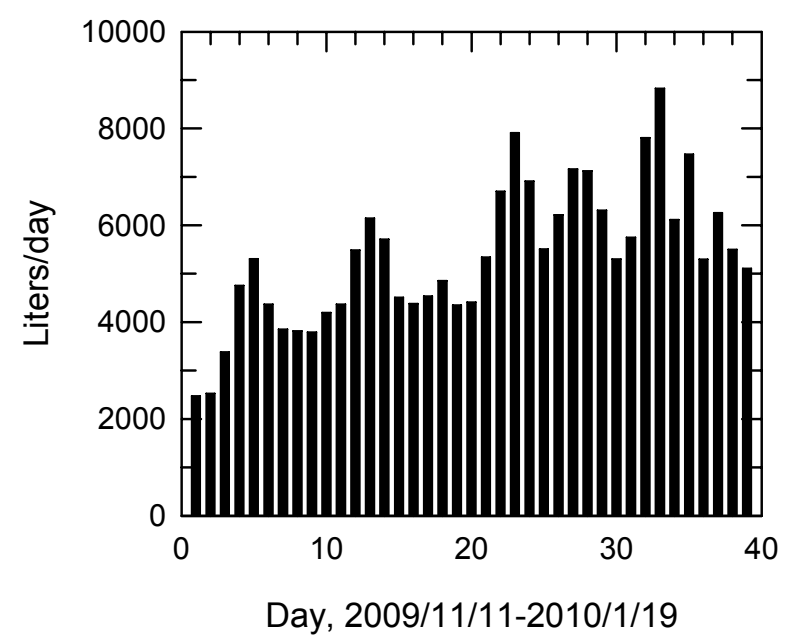

Figure 11. Relations between hot water consumption and ambient temperature.

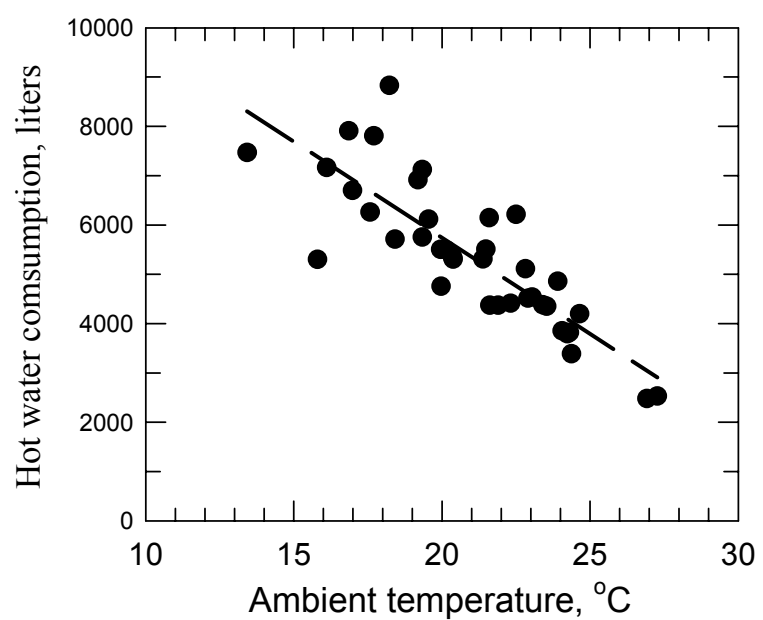

As seen in Figure 12, $\eta$ is less than $45 \%$ for the girls' dormitory system, indicating a poorer performance than that of a residential solar water heater. It is also noted that $\eta$ would be higher than $30 \%$ when the daily solar radiation per square meter exceeds $7 \mathrm{MJ} / \mathrm{m}^{2}$. In addition, the measured data showed that the water temperature at the upper level in the storage tanks was about $40{ }^{\circ} \mathrm{C}$ on most days, implying that the water was overheated the night before. Thus, improper operation of the auxiliary heater could not only lead to energy waste but also lower thermal efficiency of a solar water heater. Hot water consumption patterns, particularly on weekends and during winter vacation, should be taken into consideration for optimal control strategies, e.g., on/off of auxiliary heaters or buffer storage tanks. Furthermore, Chang et al. [12] indicated that unit price of a SWH decreases with larger area of solar collectors installed. The payback period of residential SWHs with the current subsidy program was about 5-6 years in Taiwan [11]. However, the payback period is also associated with solar insolation, energy price and $\eta$ of a SWH. The detailed cost and benefit analysis of non-residential SWHs will be reported later. 
Figure 12. Utilization efficiency of solar water heater at Li-Jen Senior High School.

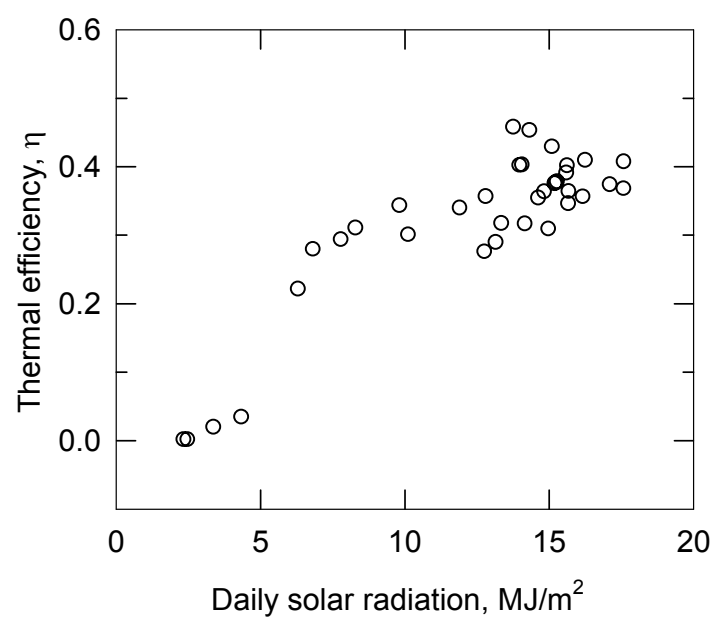

\section{Conclusions}

The current subsidy programs by the government of Taiwan have a great impact on the popularity of solar water heaters. However, the number of large-scale solar water heaters installed was still limited, and some new strategies should be enforced. According to the desk survey, most installers lack experience in system design for a large-scale solar water heater. Maintenance is another major concern. Exposure of solar collectors to salty air on casings, absorber paint and sealing deterioration should also be addressed. For the field measurements of a girls' dormitory system, the data revealed that solar contribution is less than $50 \%$ of total water heating energy in winter season, particularly at lower ambient temperatures. In terms of net energy savings, the system appears to be under-designed. Furthermore, the thermal efficiency of the system is lower than that of a residential one. Even though $\mathrm{A}_{\mathrm{SC}}$ would be the key system design criterion, hot water use pattern and operation of auxiliary heater (control strategy for on/off) should be taken into account in order to obtain better thermal performance for a dormitory SWHs. Regulation of hot water supply should be set.

\section{Acknowledgments}

The study is under the support of Bureau of Energy, Ministry of Economic Affairs, Republic of China.

\section{References}

1. Roulleau, T.; Lloyd, C.R. International policy issues regarding solar water heating, with a focus on New Zealand. Energy Policy 2008, 36, 1843-1857.

2. Weiss, W.; Bergmann, I.; Faninger, G. Solar Heat Worldwide: Markets and Contribution to the Energy Supply 2006 (Edition 2008); International Energy Agency: Paris, France, 2008.

3. Kalogirou, S. Thermal performance, economic and environmental life cycle analysis of thermosiphon solar water heaters. Sol. Energy 2009, 83, 39-48.

4. Chang, K.C.; Lin, W.M.; Lee, T.S.; Chung, K.M. Subsidy programs on diffusion of solar water heaters: Taiwan's experience. Energy Policy 2011, 39, 563-567. 
5. Papakostas, K.T.; Papageorgiou, N.E.; Sotiropoulos, B.A. Residential hot water use patterns in Greece. Sol. Energy 1995, 54, 369-374.

6. Arkar, C.; Medved, S.; Novak, P. Long-term operation experiences with large-scale solar systems in Slovenia. Renew. Energy 1999, 16, 669-672.

7. Enaburekhan, J.; Yakasai, U.T. Performance evaluation of a refrigerant-charged integrated solar water heater in northern Nigeria. Desalination 2009, 243, 208-217.

8. Chen, B.R.; Chang, Y.W.; Lee, W.S.; Chen, S.L. Long-term thermal performance of a two-phase thermosuphon solar water heater. Sol. Energy 2009, 83, 1048-1055.

9. Ayompe, L.M.; Duffy, A.; Keever, M.; Mc Conlon, M.; McCormack, S.J. Comparative field performance study of flat plate and heat pipe evacuated tube collectors (ETCs) for domestic water heating systems in a temperature climate. Energy 2011, 36, 3370-3378.

10. Chang, K.C.; Lee, T.S.; Chung, K.M. Solar water heaters in Taiwan. Renew. Energy 2006, 31, 1299-1308.

11. Chang, K.C.; Lee, T.S.; Lin, W.M.; Chung, K.M. Outlook for solar water heaters in Taiwan. Energy Policy 2008, 36, 66-72.

12. Chang, K.C.; Lin, W.M.; Lee, T.S.; Chung, K.M. Local market of solar water heaters in Taiwan: Review and perspectives. Renew. Sustain. Energy Rev. 2009, 13, 2605-2612.

13. Karagiorgas, M.; Botzios, A.; Tsoutsos, T. Industrial solar thermal applications in Greece economic evaluation, quality requirements and case studies. Renew. Sustain. Energy Rev. 2001, 5, $157-173$.

14. Degelman, L.O. Calibrated simulation of a solar water system to match degraded performance over a 22-year period using two models. Build. Environ. 2008, 43, 628-637.

(C) 2012 by the authors; licensee MDPI, Basel, Switzerland. This article is an open access article distributed under the terms and conditions of the Creative Commons Attribution license (http://creativecommons.org/licenses/by/3.0/). 